\title{
Validasi Metode Penentuan Rhodamin B dalam Contoh Saos secara Spektrofotometri UV-Vis dengan Dua Variasi Pelarut
}

\author{
Yuli Rohyami ${ }^{\text {a,* }}$, Hartiwi Putri Indah Ratri ${ }^{\text {a }}$, Wihyarti a \\ ${ }^{a}$ Program Studi DIII Analisis Kimia Fakultas Matematika dan Ilmu Pengetahuan Alam Universitas Islam Indonesia Jl. Kaliurang Km 14,5 Yogyakarta \\ * corresponding author : rohyami@uii.ac.id
}

\section{ARTIKEL INFO}

Received : 05 Juli 2018

Revised : 02 Agustus 2018

Published : 28 September 2018

Kata kunci : rhodamin B, validasi metode, spektrofotometri

\begin{abstract}
ABSTRAK
Telah dilakukan validasi metode penentuan rhodamin B pada contoh saos secara spektrofotometri UV-Vis. Validasi metode ini dilakukan dengan menggunakan dua variasi, yaitu metanol dan etanol. Contoh saos ditambah dengan larutan $\mathrm{HCl}$ dan diekstrak dengan menggunakan pelarut metanol dan etanol. Penentuan rhodamin B dilakukan dengan menggunakan spektrofotometri UVVis dengan teknik kurva kalibrasi. Berdasarkan data hasil validasi metode penentuan rhodamin $\mathrm{B}$ dengan menggunakan pelarut metanol dan etanol diperoleh kurva kalibrasi dengan lineritas 0,9996 dan 0,9989 dengan nilai LOD 0,1121 dan $0,1685 \mathrm{mg} / \mathrm{kg}$ serta nilai LOQ 0,3737 dan $0,5617 \mathrm{mg} / \mathrm{kg}$. Hasil pengujian dengan replikasi 7 kali menunjukkan bahwa kandungan rhodamin $\mathrm{B}$ dalam contoh saos dengan pelarut methanol dan etanol rata-rata adalah 2,4811 dan 2,4218 $\mathrm{mg} / \mathrm{L}$. Uji rerata dengan selang kepercayaan $95 \%$ diperoleh nilai $t_{\text {hitung }}=0,3041<t_{\text {tabel }}=1,9431$ yang menunjukkan bahwa tidak ada perbedaan signifikan antara pengujian dengan pelarut metanol dan etanol. Simpangan baku relatif penentuan rhodamin $\mathrm{B}$ dengan pelarut metanol dan etanol berturut-turut $15,84 \%$ dan $8,32 \%$ kurang dari koefisien variansi Horwitznya, sehingga kedua jenis pelarut memiliki presisi yang baik. Hasil uji akurasi menunjukkan bahwa penentuan rhodamin B secara spektrofotometri UV-Vis dengan pelarut metanol dan etanol memiliki akurasi yang baik dengan rata-rata 82,68\% dan 93,18\%. Kedua jenis pelarut memberikan persen recovery yang berada pada rentang $80-110 \%$. Penggunaan pelarut etanol memberikan akurasi yang lebih tinggi dibandingkan dengan pelarut metanol. Berdasarkan hasil uji statistika dengan selang kepercayaan 95\% diperoleh nilai $\mathrm{t}_{\text {hitung }}=1,5123<\mathrm{t}_{\text {tabel }}=2,5706$. Berdasarkan hasil uji statistik menunjukkan bahwa tidak ada perbedaan signifikan terhadap akurasi pengujian rhodamin B dengan pelarut metanol dan etanol. Kandungan rhodamin B dalam contoh saos yang dianalisis menggunakan pelarut metanol dan etanol adalah 2,4811 $\pm 0,3378 \mathrm{mg} / \mathrm{kg}$ dan $2,4217 \pm 0,4158 \mathrm{mg} / \mathrm{kg}$.
\end{abstract}

\section{PENDAHULUAN}

Indonesia memiliki kekayaan kuliner yang berasal dari tradisi warisan nusantara. Kekayaan kuliner Indonesia sangat khas dengan rempah-rempah dan bahan alami sehingga menghasilkan cita rasa yang tinggi. Seiring dengan kemajuan teknologi pengolahan pangan, penggunaan rempahrempah dan bahan alami telah banyak digantikan dengan bahan makanan tambahan, seperti penyedap rasa, pemanis, pengawet, dan pewarna. Penggunaan bahan makanan tambahan telah diatur dosis pemakaiannya, termasuk jenis bahan tambahan harus sesuai dengan standar keamanan pangan. Apabila penggunaan bahan makanan tambahan dengan batas dosis yang diperkenankan dan penggunaan bahan kimia berbahaya dapat menyebabkan gangguan kesehatan. 
Salah satu penyalahgunaan bahan kimia berbahaya sebagai bahan tambahan adalah penggunaan rhodamin B sebagai pewarna makanan. Rhodamin B digunakan untuk memberikan warna merah yang kuat pada berbagai produk makanan, jajanan anak, saos, dan pewarna minuman. Rhodamin B menggantikan pewarna makanan dengan harga yang lebih murah dan praktis. Rodhamin termasuk zat warna sintesis yang digunakan sebagai pewarna tekstil sehingga dilarang keras sebagai pewarna makanan. Rhodamin B termasuk zat aditif yang digunakan sebagi pewarna dalam industri tekstil yang bersifat karsinogenik dan dapat menimbulkan gangguan kesehatan berkepanjangan [1].

Rhodamin B banyak digunakan sebagai pewarna makanan dan minuman seperti kerupuk, permen, sirup, minuman kemasan, manisan, jajanan pasar dan aneka jajanan anak. Penambahan rhodamin B akan membuat makanan dan minuman menjadi lebih menarik dengan warna merah terang. Oleh karena itu perlu dilakukan pengawasan yang ketat untuk memastikan adanya pelanggaran standar keamanan pangan. Salah satu upaya dalam meningkatan pengawasan keamanan pangan juga perlu didukung laboratorium yang mampu menerapkan sistem manajemen laboratorium terstandar yang didukung dengan metode uji yang telah divalidasi.

Pengujian rhodamin B dapat dilakukan dengan menggunakan metode high performence liquid chromatography [2], kromatografi lapis tipis [3], dan spektrofotometri UV-Vis. Spektrofotometri UV-Vis merupakan metode pengujian rhodamin B yang dapat dilakukan dengan mudah dan murah. Rhodamin B merupakan zat warna tekstil yang memiliki intensitas warna yang kuat sehingga dapat diamati pada daerah visible. Cemaran rhodamin terdapat dalam makanan dan minuman yang memiliki efek matrik yang kompleks sehingga diperlukan preparasi contoh uji yang memiliki selektivitas yang tinggi. Rhodamin B dapat larut dengan baik dalam air dan alkohol, sehingga pelarut air dan alkohol dapat digunakan sebagai pelarut dalam preparasi pengujian.

Preparasi pengujian rhodamin B dalam contoh makanan dengan spektrofotometri UV-Vis dapat dilakukan melalui preparasi contoh uji dengan pelarut etanol $[3,4]$. Ada dua jenis alkohol yang lazim digunakan sebagai pelarut, yaitu metanol dan etanol [5]. Kedua pelarut tersebut dapat digunakan dalam preparasi contoh uji yang dilakukan dengan cara melarutkan rhodamin B dengan pelarut. Teknik ekstraksi menjadi salah satu prosedur preparasi contoh uji yang dapat dilakukan dengan berbagai teknik. Jumlah pelarut yang digunakan menjadi pertimbangan efisiensi dan cara meminimalkan bahan kimia yang akan menyisakan limbah laboratorium. Prekonsentrasi atau mikroekstraksi merupakan salah satu cara mudah dalam pengujian analit dalam rentang konsentrasi yang kecil sehingga dapat meminimalkan penggunaan pelarut [6].

\section{METODE}

\subsection{Bahan dan Peralatan}

Bahan yang digunakan dalam penelitian ini adalah larutan standar rhodamin $\mathrm{B}$ $\left(\mathrm{C}_{28} \mathrm{H}_{31} \mathrm{ClN}_{2} \mathrm{O}_{3}\right)$, methanol $\left(\mathrm{CH}_{4} \mathrm{O}\right)$, etanol $\left(\mathrm{C}_{2} \mathrm{H}_{6} \mathrm{O}\right)$, asam klorida $(\mathrm{HCl})$, dan asam sufat anhidrat $\left(\mathrm{Na}_{2} \mathrm{SO}_{4}\right)$ yang diproduksi oleh Merck. Bahan lain yang digunakan adalah kertas saring Whatman 41, akuades yang dibuat oleh Laboratorium Kimia Terapan Fakultas Matematika dan Ilmu Pengetahuan Alam Universitas Islam Indonesia. Peralatan yang digunakan adalah peralatan gelas laboratorium, pipet ukur $1 \pm 0,006 \mathrm{~mL}$, labu takar $10 \pm 0,025 \mathrm{~mL}$, pipet ukur $10 \pm 0,05 \mathrm{~mL}$ dan labu takar $25 \pm 0,004 \mathrm{~mL}$, neraca analitik Ohaus, dan spektrofotometer UV-Vis doublebeam Hitachi U-5300.

\subsection{Pembuatan Larutan Induk Rhodamin B $1.000 \mathrm{mg} / \mathrm{L}$}

Larutan induk rhodamin B dibuat dengan dua jenis pelarut. Larutan induk pertama menggunakan pelarut methanol dan larutan induk kedua dengan menggunakan pelarut etanol. Sebanyak 0,010 gram rhodamin B dimasukan ke dalam gelas beaker $100 \mathrm{~mL}$ dan dengan pelarut pelarut. Larutan dipindahkan ke dalam labu ukur $10 \mathrm{~mL}$ dan ditepatkan dengan pelarut kemudian dihomogenkan. 


\subsection{Pembuatan Larutan Standar Rhodamin B $50 \mathrm{mg} / \mathrm{L}$}

Sebanyak 12,5 mL larutan induk rhodamin B $1000 \mathrm{mg} / \mathrm{L}$ dimasukan ke dalam labu ukur 25 $\mathrm{mL}$ kemudian ditepatkan volumenya dengan pelarut sampai tanda batas dan dihomogenkan.

\subsection{Pembuatan Deret Standar dan Kurva Kalibrasi Larutan Standar Rhodamin B}

Sebanyak $1 ; 1,5 ; 2 ; 2,5$; dan $3 \mathrm{~mL}$ larutan standar rodhamin B dipipet kemudian dimasukkan ke dalam labu ukur $10 \mathrm{~mL}$ kemudian ditepatkan volume untuk membuat deret larutan baku 1; 1,5; 2; 2,5; dan $3 \mathrm{mg} / \mathrm{L}$ dengan pelarut. Larutan diukur absorbansinya pada kisaran panjang gelombang $550 \mathrm{~nm}$ dengan spektrofotometer UV-Vis. Data absorbansi larutan standar digunakan untuk membuat kurva kalibrasi larutan standar rhodamin B, lineritas, standar deviasi residual, limit of detection (LOD), dan limit of quantification (LOQ).

\subsection{Penentuan Rhodamin B pada Sampel Makanan}

Penentuan rhodamin B dilakukan dengan menggunakan dua variasi pelarut, yaitu methanol dan etanol. Sebanyak 2 gram sampel saos dimasukan ke dalam gelas beaker ditambah 16 tetes $\mathrm{HCl}$ $4 \mathrm{M}$ dan $10 \mathrm{~mL}$ pelarut kemudian diaduk sampai homogen. Larutan disaring dengan kertas saring yang pada bagian atasnya ditambahkan natrium sulfat anhidrat. Filtrat yang diperoleh dimasukan ke dalam labu ukur $10 \mathrm{~mL}$ kemudian ditepatkan volumenya hingga $10 \mathrm{~mL}$. Larutan dihomogenkan dan dikukur absorbansinya pada panjang gelombang $550 \mathrm{~nm}$ dengan spektrofotometer UV-Vis [6]. Pengujian dilakukan dengan replikasi tujuh kali untuk menentukan presisi.

\subsection{Penentuan Akurasi dari \% Recovery}

Sebanyak 2 gram sampel saos dimasukan ke dalam gelas beaker ditambah $0,1 \mathrm{~mL}$ larutan standar rhodamin B $50 \mathrm{mg} / \mathrm{L}, 16$ tetes $\mathrm{HCl} 4 \mathrm{M}$ dan $10 \mathrm{~mL}$ pelarut kemudian diaduk sampai homogen. Larutan disaring dengan kertas saring yang pada bagian atasnya ditambahkan natrium sulfat anhidrat. Filtrat yang diperoleh dimasukan ke dalam labu ukur $10 \mathrm{~mL}$ kemudian ditepatkan volumenya hingga $10 \mathrm{~mL}$. Larutan dihomogenkan dan dikukur absorbansinya pada panjang gelombang $550 \mathrm{~nm}$ dengan spektrofotometer UV-Vis. Penentuan akurasi dihitung dari persentase recovery.

\section{HASIL PENELITIAN}

\subsection{Pembuatan Kurva Kalibrasi Larutan Standar Rhodamin B dan Penentuan Linieritas}

Hasil pengukuran absorbansi larutan standar rhodamin B 1; 1,5;2; 2,5; dan $3 \mathrm{mg} / \mathrm{L}$ disajikan dalam Tabel 1. Tabel 1 menunjukkan data absorbansi larutan standar rhodamin B dengan menggunakan dua pelarut yang berbeda, yaitu metanol dan etanol. Berdasarkan data pada Tabel 1 dapat dibuat kurva kalibrasi larutan standar yang disajikan pada Gambar 1. Berdasarkan data dapat diperoleh persamaan regresi linier $\mathrm{Y}=0,2148 \mathrm{X}+0,0010$ untuk larutan standar rhodamin $\mathrm{B}$ dalam pelarut metonal dan $\mathrm{Y}=0,2092 \mathrm{X}-0,0013$ dalam pelarut etanol. Berdasarkan data hasil pengujian, larutan standar rhodamin B yang dilarutkan dalam pelarut methanol memiliki koefisien korelasi 0,9996 sedangkan kurva kalibrasi larutan standar rhodamin B dalam pelarut etanol adalah 0,9989. Kedua kurva kalibrasi memiliki koefisien determinasi (R2) masing-masing 0,9999 dan 0,9978, sehingga lebih dari 99\% dari data larutan standar memiliki hubungan yang linier. Kedua deret standar rhodamin B dalam pelarut methanol dan etanol memiliki koefisien korelasi $\geq 0,99$ sehingga kedua kurva kalibrasi memiliki linieritas yang baik. Larutan standar rhodamin B yang telah disiapkan dengan menggunakan pelarut metanol dan etanol memiliki lineritas yang baik. Rentang linieritas kurva kalibrasi larutan standar rhodamin B berada pada kisaran 1,5 - 70 $\mu \mathrm{g} / \mathrm{L}$ [6].

\subsection{Penentuan LOD dan LOQ}

Penentuan LOD dan LOQ didasarkan pada data pengukuran absorbansi deret standar dan persamaan regresi linier. Data absorbansi masing-masing deret standar dikoreksi dengan menggunakan persamaan regresi linier $\mathrm{Y}=0,2148 \mathrm{X}+0,0035$ dan $\mathrm{Y}=0,2092 \mathrm{X}-0,0015$. Selisih nilai absorbansi hasil pengukuran dan absorbansi yang telah dikoreksi digunakan untuk menghitung standar deviasi residual.

Copyright $@$ 2018, Indonesian Journal of Chemical Analysis, ISSN 2622-7401, e ISSN 2622-7126 
Berdasarkan data hasil pengukuran kurva kalibrasi pada Tabel 2 menunjukkan bahwa nilai LOD kedua larutan standar 0,1121 dan $0,1685 \mathrm{mg} / \mathrm{L}$. Nilai LOD memberikan informasi bahwa penentuan rhodamin B dengan menggunakan pelarut methanol dan etanol dapat dideteksi dan dapatmemberikan respon signifikan terhadap spektrofotometer UV-Visible. Batas kuantifikasi ditunjukkan dengan nilai LOQ, masing-masing 0,3737 dan $0,5617 \mathrm{mg} / \mathrm{L}$. Penentuan rhodamin $\mathrm{B}$ dengan pelarut metanol di atas $0,3737 \mathrm{mg} / \mathrm{L}$ dapat memenuhi kriteria secara cermat dan seksama. Penggunaan pelarut metanol memiliki batas kuantifikasi yang lebih rendah di bandingkan dengan pelarut etanol. Batas kuantifikasi penentuan rhodamin B dengan pelarut etanol adalah 0,5617 mg/L. Kedua nilai batas deteksi digunakan untuk menentukan kecermatan dan keseksamaan data hasil pengujian rhodamin B dalam contoh saos.

TABEL 1. Hasil pengukuran absorbansi larutan standar rhodamin B

\begin{tabular}{cccc}
\hline \multirow{2}{*}{ No } & Konsentrasi larutan standar rhodamin B $(\mathrm{mg} / \mathrm{L})$ & \multicolumn{2}{c}{ Absorbansi larutan standar dengan pelarut } \\
\cline { 3 - 4 } & & 0,000 & Etanol \\
\hline 1 & 0 & 0,215 & 0,000 \\
2 & 1 & 0,333 & 0,215 \\
3 & 1,5 & 0,443 & 0,294 \\
4 & 2 & 0,535 & 0,428 \\
5 & 2,5 & 0,644 & 0,516 \\
6 & 3 & & 0,630 \\
\hline
\end{tabular}

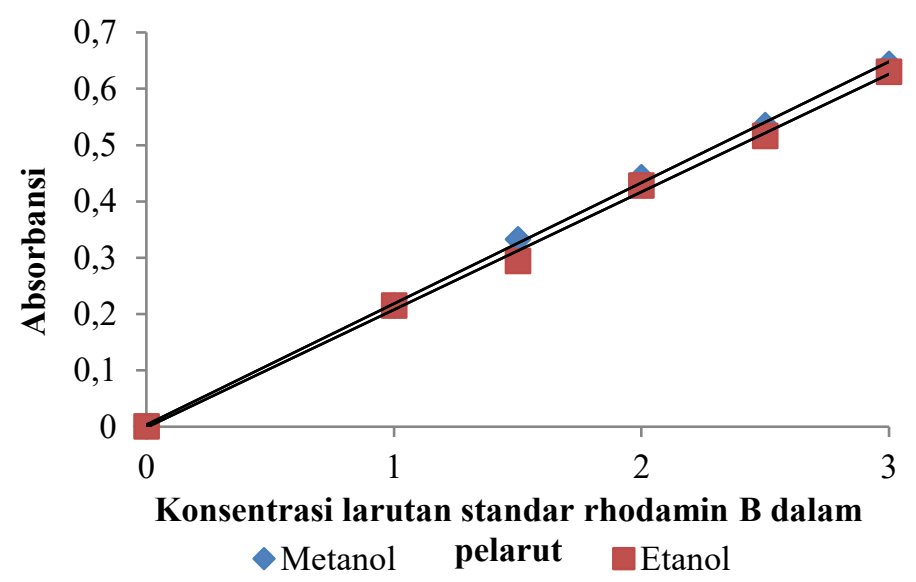

Gambar 1. Kurva kalibrasi larutan rhodamin B

TABEL 2. Batas Absorbansi larutan standar rhodamin B dengan pelarut etanol

\begin{tabular}{|c|c|c|c|c|c|c|c|}
\hline \multirow[t]{2}{*}{ No } & \multirow{2}{*}{$\begin{array}{l}\text { Konsentrasi } \\
\text { larutan standar } \\
(\mathrm{mg} / \mathrm{L})\end{array}$} & \multicolumn{3}{|c|}{$\begin{array}{c}\text { Absorbansi larutan standar rhodamin dengan } \\
\text { pelarut metanol }\end{array}$} & \multicolumn{3}{|c|}{$\begin{array}{c}\text { Absorbansi larutan standar rhodamin } \\
\text { dengan pelarut etanol }\end{array}$} \\
\hline & & $\mathrm{y}_{\mathrm{i}}$ & $\mathrm{y}_{\mathrm{c}}$ & $\left(y_{i}-y_{c}\right)^{2}$ & $\mathrm{y}_{\mathrm{i}}$ & $\mathrm{y}_{\mathrm{c}}$ & $\left(y_{i}-y_{c}\right)^{2}$ \\
\hline 1. & 0 & 0 & 0,0036 & $1,30 \times 10^{-6}$ & 0 & $-0,0013$ & $1,69 \times 10^{-6}$ \\
\hline 2. & 1 & 0,215 & 0,216 & $1,23 \times 10^{-6}$ & 0,215 & 0,2079 & $5,78 \times 10^{-5}$ \\
\hline 3. & 1,5 & 0,335 & 0.3235 & $4,97 \times 10^{-5}$ & 0,295 & 0,3125 & $3,24 \times 10^{-4}$ \\
\hline 4. & 2 & 0,443 & 0,431 & $9,21 \times 10^{-4}$ & 0,428 & 0,4171 & $1,19 \times 10^{-4}$ \\
\hline 5. & 2,5 & 0,535 & 0,5385 & $3,42 \times 10^{-5}$ & 0,516 & 0,5217 & $3,25 \times 10^{-5}$ \\
\hline \multirow[t]{4}{*}{6.} & 3 & 0,644 & 0,646 & $1,85 \times 10^{-5}$ & 0,631 & 0,6263 & $1,76 \times 10^{-5}$ \\
\hline & & \multicolumn{2}{|c|}{ Standar deviasi residual } & $7,41 \times 10^{-3}$ & \multicolumn{2}{|c|}{ Standar deviasi residual } & 0,0117 \\
\hline & & \multicolumn{2}{|c|}{ LOD } & $0,1035 \mathrm{mg} / \mathrm{kg}$ & & LOD & $0,1685 \mathrm{mg} / \mathrm{kg}$ \\
\hline & & \multicolumn{2}{|c|}{ LOQ } & $0,3545 \mathrm{mg} / \mathrm{kg}$ & & LOQ & $0,5617 \mathrm{mg} / \mathrm{kg}$ \\
\hline
\end{tabular}

Copyright (C) 2018, Indonesian Journal of Chemical Analysis, ISSN 2622-7401, e ISSN 2622-7126 


\subsection{Penentuan Rhodamin B}

Penentuan kadar rhodamin B dalam contoh saus sambal yang diekstrak dengan pelarut methanol disajikan dalam Tabel 3. Berdasarkan hasil pengujian dengan replikasi 7 kali menunjukkan bahwa kandungan rhodamin $\mathrm{B}$ dalam contoh saos dengan pelarut methanol dan etanol rata-rata adalah 2,4811 dan $2,4218 \mathrm{mg} / \mathrm{L}$. Berdasarkan hasil uji rerata dengan selang kepercayaan $95 \%$ diperoleh nilai $\mathrm{t}_{\text {hitung }}=0,3041<\mathrm{t}_{\text {tabel }}=1,9431$. Berdasarkan hasil uji statistik menunjukkan bahwa tidak ada perbedaan signifikan antara pengujian dengan pelarut metanol dan etanol. Rhodamin B dapat larut dalam alkohol, sehingga penggunakan pelarut metanol dan etanol tidak memberikan perbedaan yang signifikan terhadap hasil pengujian.

TABEL 3. Kandungan rhodamin B dalam contoh saos

\begin{tabular}{cccc}
\hline No & Replikasi & \multicolumn{2}{c}{ Konsentrasi rhodamin B dalam pelarut $(\mathrm{mg} / \mathrm{kg})$} \\
\cline { 3 - 4 } & & Metanol & Etanol \\
\hline 1 & 1 & 1,8625 & 2,3970 \\
2 & 2 & 3,0695 & 2,1170 \\
3 & 3 & 2,7125 & 2,5090 \\
4 & 4 & 2,5605 & 2,2925 \\
5 & 5 & 2,5455 & 2,6915 \\
6 & 6 & 2,5020 & 2,3185 \\
7 & 7 & 2,1152 & 2,6270 \\
\hline & rata-rata & 2,4811 & 2,4218 \\
\hline
\end{tabular}

\subsection{Penentuan Presisi}

Presisi metode uji ditentukan dari data pengujian contoh dengan replikasi 7 kali. Presisi dihitung dari nilai simpangan baku relatif seperti yang ditunjukkan pada Tabel 4. Data Tabel 4 menunjukkan presisi penentuan rhodamin B menggunakan metode spektrofotometri UV-Vis dengan dua variasi pelarut metanol dan etanol. Simpangan baku relatif penentuan rhodmin B dengan pelarut metanol dan etanol berturut-turut $15,84 \%$ dan $8,32 \%$. Berdasarkan hasil pengujian, simpangan baku relatif memiliki nilai $\geq 2 \%$. Menurut Association of Official Analytical Chemist, presisi metode yang baik apabila nilai simpangan baku relatifnya $\leq 2 \%$. Apabila nilai simpangan baku relatifnya $\geq 2 \%$, maka dapat dibandingkan dengan koefisien variansi Horwitz (CV Horwitz). Berdasarkan data koefisien variansi Horwitz pada Tabel 3 dapat ditunjukkan bahwa penentuan rhodamin B dengan pelarut metanol dan etanol memiliki presisi yang baik, dengan simpangan baku relatif kurang dari koefisien variansi Horwitznya.

TABEL 4. Data penentuan presisi

\begin{tabular}{lcc}
\hline \multirow{2}{*}{ Parameter } & \multicolumn{2}{c}{ Penentuan rhodamin B dengan pelarut } \\
\cline { 2 - 3 } & Metanol & Etanol \\
\hline Simpangan baku & $0,3931 \mathrm{mg} / \mathrm{kg}$ & $0,2014 \mathrm{mg} / \mathrm{kg}$ \\
Simpangan baku relatif & $15,84 \%$ & $8,32 \%$ \\
CV Horwitz & 1,7443 & 1,7507 \\
\hline
\end{tabular}

\subsection{Penentuan Akurasi}

Penentuan akurasi digunakan untuk menunjukkan derajat kedekatan hasil analisis dengan konsentrasi yang sebenarnya. Akurasi pengujian rhodamin B dengan metode spektrofotometri UVVis dilakukan melalui penentuan persentase temu balik (\% recovery) dengan metode simulasi (spiked-plasebo recovery). Data penentuan akurasi dengan penambahan $0,1 \mathrm{~mL}$ larutan standar rhodamin B 50 ppm disajikan pada Tabel 5.

Berdasarkan hasil uji akurasi menunjukkan bahwa penentuan rhodamin B secara spektrofotometri UV-Vis dengan pelarut metanol dan etanol memiliki akurasi yang baik dengan rata-rata $82,68 \%$ dan $93,18 \%$. Kedua jenis pelarut memberikan persen recovery yang berada pada rentang $80-110 \%$. Penggunaan pelarut etanol memberikan akurasi yang lebih tinggi dibandingkan 
dengan pelarut metanol. Berdasarkan hasil uji statistika dengan selang kepercayaan 95\% diperoleh nilai $\mathrm{t}_{\text {hitung }}=1,5123<\mathrm{t}_{\text {tabel }}=2,5706$. Berdasarkan hasil uji statistik menunjukkan bahwa tidak ada perbedaan signifikan terhadap akurasi pengujian rhodamin B dengan pelarut metanol dan etanol.

TABEL 5. Data penentuan persentase recovery

\begin{tabular}{cccc}
\hline No & Contoh spike & \multicolumn{2}{c}{ \% Recovery contoh spike dengan pelarut } \\
\cline { 3 - 4 } & & Metanol & Etanol \\
\hline 1 & 1 & 77,70 & 110,14 \\
2 & 2 & 78,26 & 110,74 \\
3 & 3 & 82,66 & 82,34 \\
4 & 4 & 82,74 & 81,86 \\
5 & 5 & 87,10 & 86,24 \\
6 & 6 & 87,60 & 87,76 \\
& Rata-rata & 82,68 & 93,18 \\
\hline
\end{tabular}

\subsection{Penentuan Estimasi Ketidakpastian Pengukuran}

Penentuan estimasi ketidakpastian pengukuran dilakukan dengan enam langkah, yaitu 1) membuat skema kerja; 2) menentukan rumus; 3) membuat diagram tulang ikan; 4) menentukan sumber ketidakpastian pengukuran dan menghitung ketidakpastian baku relatif; 5) menentukan ketidakpastian gabungan; dan 6) menentukan ketidakpastian diperluas.

Skema kerja penentuan rhodamin B dalam contoh saos disajikan pada Gambar 2. Berdasarkan Gambar 2 dapat diidentifikasi sumber penyumbang ketidakpastian pengukuran. Sumber penyumbang ketidakpastian pengukuran diperoleh dari proses yang memberikan kontribusi terhadap ketertelusuran hasil pengujian yang meliputi penimbangan contoh saos, pengenceran, pengukuran konsentrasi rhodamin dengan spektrofotometer UV-Vis dengan menggunakan teknik kurva kalibrasi, dan replikasi pengujian.

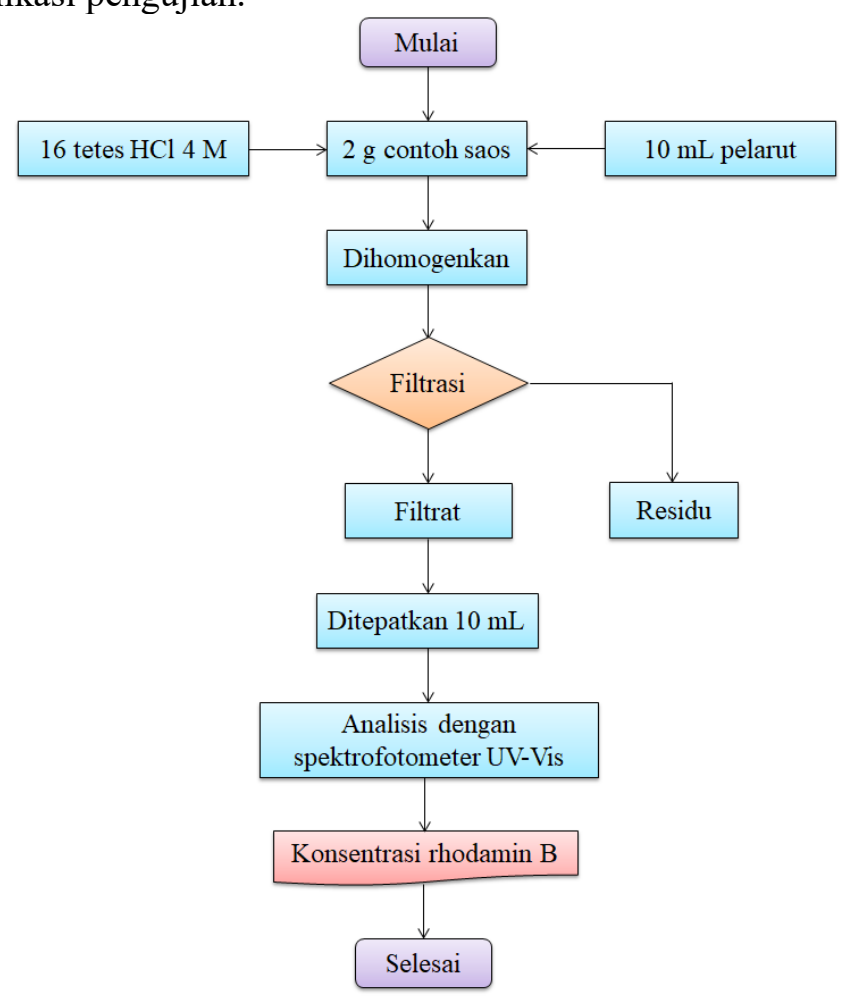

Gambar 2. Skema kerja penentuan kadar rhodamin B 
Konsentrasi rhodamin B dalam contoh uji dihitung dengan menggunakan persamaan sebagai berikut:

$$
\text { konsentrasi rhodamin B }(\mathrm{mg} / \mathrm{kg})=\frac{\mathrm{X} \times \mathrm{V}}{\mathrm{W}} \times 100 \%
$$

$\mathrm{X}:$ konsentrasi dalam contoh $(\mathrm{mg} / \mathrm{L})$

$\mathrm{V}$ : volume contoh (L)

$\mathrm{W}$ : bobot contoh $(\mathrm{kg})$

Konsentrasi rhodamin B dihitung dari konsentrasi yang didapatkan dari plot absorbansi contoh dengan persamaan regresi linier. Konsentrasi dikonversi dalam satuan $\mathrm{mg} / \mathrm{kg}$, sehingga volume larutan dan massa contoh uji digunakan untuk menaksirkan konsentrasi rhodamin B. Berdasarkan persamaan di atas, maka ketidakpastian konsentrasi contoh dipengaruhi dari sumber ketidakpastian yang berasal dari kurva kalibrasi larutan standar.

Berdasarkan skema kerja dan persamaan yang digunakan dalam penentuan konsentrasi rhodamin B, maka dapat diidentifikasi sumber ketidakpastian pengukuran. Hasil identifikasi sumer ketidakpastian disajikan pada Gambar 3. Gambar 3 menunjukkan diagram tulang ikan yang menunjukkan yang berasal dari 1) ketidakpastian konsentrasi yang berasal dari kurva kalibrasi, 2) massa contoh yang berasal dari data kalibrasi neraca, 3) pengenceran contoh uji dan pengenceran deret larutan standar, 4) repeatabilitas yang berasal dari presisi pengukuran contoh uji; dan 5) kemurnian standar.

Seluruh faktor penting yang dianggap berkontribusi terhadap nilai ketidakpastian pada penentuan konsentrasi rhodamin B diidentifikasi untuk menentukan nilai ketidakpastian baku. Hasil perhitungan ketidakpastian baku dan ketidakpastian relatif

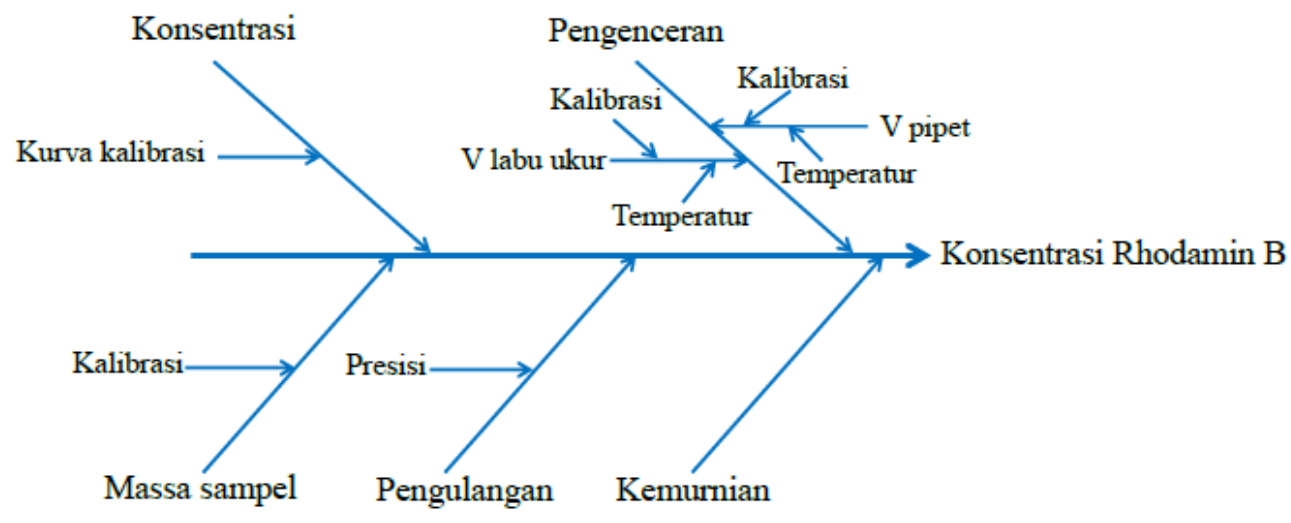

Gambar 3. Diagram ikan sumber ketidakpastian pengukuran penentuan rhodamin B

TABEL 6. Nilai ketidakpastian pengukuran penentuan rhodamin B dengan pelarut metanol

\begin{tabular}{|c|c|c|c|c|c|c|c|c|}
\hline \multirow[t]{2}{*}{ No. } & \multirow[t]{2}{*}{ Ketidakpastian Asal } & \multirow[t]{2}{*}{ satuan } & \multicolumn{3}{|c|}{ Menggunakan pelarut metanol } & \multicolumn{3}{|c|}{ Menggunakan pelarut etanol } \\
\hline & & & Nilai $\mathrm{x}$ & $\begin{array}{l}\text { Ketidakpastian } \\
\text { baku }\left(\mathrm{U}_{\mathrm{x}}\right)\end{array}$ & $\begin{array}{l}\text { Ketidakpastian } \\
\text { relatif }(\mathrm{Ux} / \mathrm{x})\end{array}$ & Nilai $\mathrm{x}$ & $\begin{array}{l}\text { Ketidakpastian } \\
\text { baku }\left(U_{x}\right)\end{array}$ & $\begin{array}{c}\text { Ketidakpastian } \\
\text { relatif }(\mathrm{Ux} / \mathrm{x})\end{array}$ \\
\hline 1 & Neraca analitik & $\mathrm{g}$ & 2,0068 & 0,00008 & 0,000004 & 2,0220 & 0,00008 & 0,000004 \\
\hline 2 & Pipet volume & $\mathrm{mL}$ & 10 & 0,0868 & 0,0087 & 10 & 0,0868 & 0,0087 \\
\hline 3 & Labu ukur & $\mathrm{mL}$ & 10 & 0,0301 & 0,0030 & 10 & 0,0301 & 0,0030 \\
\hline 4 & Labu ukur & $\mathrm{mL}$ & 25 & 0,2120 & 0,0085 & 25 & 0,2120 & 0,0085 \\
\hline 5 & Kemurnian standar & $\%$ & 95 & 0,0577 & 0,0006 & 95 & 0,0577 & 0,0006 \\
\hline 6 & Kurva kalibrasi & $\mathrm{mg} / \mathrm{kg}$ & 2,4811 & 0,0111 & 0,0045 & 2,4217 & 0,0175 & 0.0072 \\
\hline \multirow[t]{3}{*}{7} & Pengulangan & - & 7 & 0,0016 & 0,0002 & 7 & 0,0008 & 0,0001 \\
\hline & \multirow{2}{*}{\multicolumn{3}{|c|}{$\begin{array}{l}\text { Ketidakpastian gabungan } \\
\text { Ketidakpastian diperluas }\end{array}$}} & & $0,1689 \mathrm{mg} / \mathrm{kg}$ & & & $0,2080 \mathrm{mg} / \mathrm{kg}$ \\
\hline & & & & & $0,3378 \mathrm{mg} / \mathrm{kg}$ & & & $0,4158 \mathrm{mg} / \mathrm{kg}$ \\
\hline
\end{tabular}




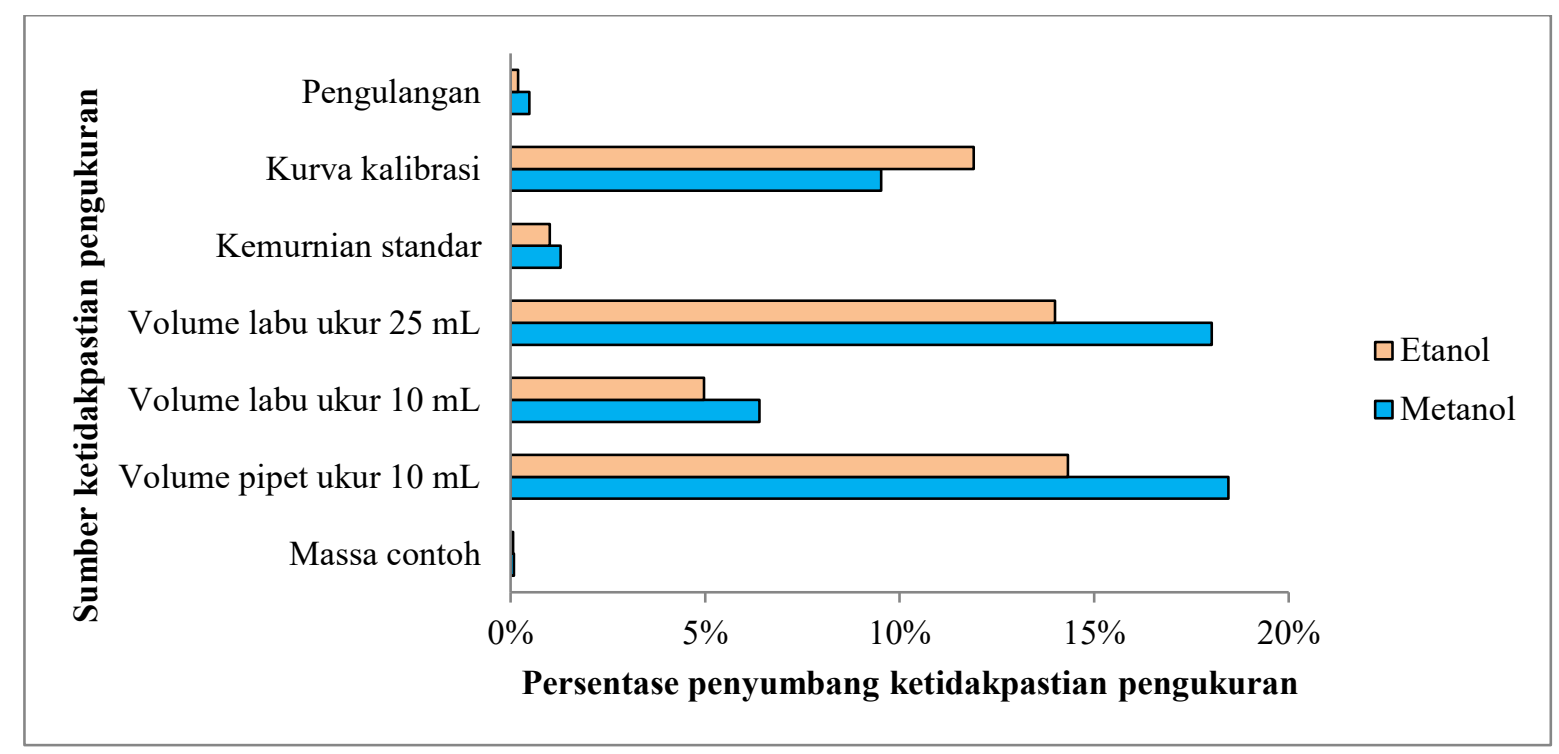

Gambar 4. Estimasi nilai sumber ketidakpastian pengukuran penentuan rhodamin B

Nilai sumber ketidakpastian pengukuran dengan selang kepercayaan 95\% disajikan pada Tabel 6 dan Gambar 4. Tabel 6 menunjukkan nilai ketidakpastian pengukuran dari sumber-sumber ketidakpastian sesuai dengan diagram tulang ikan pada Gambar 3. Berdasarkan hasil perhitungan nilai ketidakpastian diperluas pada pengukuran rhodamin B dengan pelarut metanol dan etanol masing-masing 0,3378 dan 0,4158 $\mathrm{mg} / \mathrm{kg}$. Kontribusi terbesar sebagai penyumbang ketidakpastian pengukuran rhodamin $\mathrm{B}$ berasal dari volume labu ukur $25 \mathrm{~mL}$ dan pipet ukur $10 \mathrm{~mL}$ yang digunakan sebagai alat ukur pada pembuatan deret larutan standar. Hal ini menunjukkan bahwa pemilihan alat ukur volumetrik dapat memberikan pengaruh terhadap sumber kesalahan dalam pengujian kimia. Berdasarkan data histogram pada Gambar 4. Menunjukkan bahwa volume pipet ukur dan labu ukur memberikan kontribusi masing-masing $18 \%$ untuk penggunaan pelarut metanol dan $14 \%$ untuk penggunaan pelarut etanol. Jenis pelarut tidak memberikan perbedaan terhadap kontribusi penyumbang ketidakpastian pengukuran. Ketidakpastian relatif dari kurva kalibrasi untuk penggunaan pelarut metanol dan etanol adalah 0,0045 dan 0,0072. Kedua nilai ini memyumbangkan 10 dan 12\% terhadap nilai ketidakpastian gabungan penentuan rhodamin $\mathrm{B}$.

Berdasarkan hasil rerata pengujian rhodamin B dengan menggunakan dua jenis pelarut disertai dengan data hasil penentuan estimasi ketidakpastian pengukuran dapat diperoleh data yang disajikan pada Tabel 7. Berdasarkan data pada Tabel 7 dapat ditunjukkan bahwa kandungan rhodamin B dalam contoh saos yang dianalisis menggunakan pelarut metanol dan etanol adalah $2,4811 \pm 0,3378 \mathrm{mg} / \mathrm{kg}$ dan $2,4217 \pm 0,4158 \mathrm{mg} / \mathrm{kg}$. Berdasarkan hasil uji presisi menunjukkan bahwa kedua jenis pelarut tidak memberikan pengaruh yang signifikan terhadap hasil pengujian, namun penggunaan jenis pelarut ini hanya berpengaruh pada perbedaan polaritas dan koefisien absorptivitas molar [5].

TABEL 7. Rerata hasil pengujian rhodamin B dan nilai estimasi ketidakpastian pengukuran

\begin{tabular}{clc}
\hline No. & \multicolumn{1}{c}{ Pengujian } & Konsentrasi rhodamin B \\
\hline 1. & Contoh saos dalam pelarut metanol & $2,4811 \pm 0,3378 \mathrm{mg} / \mathrm{kg}$ \\
2. & Contoh saos dalam pelarut etanol & $2,4217 \pm 0,4158 \mathrm{mg} / \mathrm{kg}$ \\
\hline
\end{tabular}

\section{KESIMPULAN}

Berdasarkan data hasil validasi metode penentuan rhodamin B dengan menggunakan pelarut metanol dan etanol diperoleh kurva kalibrasi dengan lineritas 0,9996 dan 0,9989 dengan nilai LOD 0,1121 dan $0,1685 \mathrm{mg} / \mathrm{kg}$ serta nilai LOQ 0,3737 dan $0,5617 \mathrm{mg} / \mathrm{kg}$. Hasil pengujian dengan replikasi 7 kali menunjukkan bahwa kandungan rhodamin $\mathrm{B}$ dalam contoh saos dengan 
pelarut methanol dan etanol rata-rata adalah 2,4811 dan 2,4218 mg/L. Berdasarkan hasil uji rerata dengan selang kepercayaan $95 \%$ diperoleh nilai $t_{\text {hitung }}=0,3041<\mathrm{t}_{\text {tabel }}=1,9431$ yang menunjukkan bahwa tidak ada perbedaan signifikan antara pengujian dengan pelarut metanol dan etanol. Simpangan baku relatif penentuan rhodamin B dengan pelarut metanol dan etanol berturut-turut $15,84 \%$ dan $8,32 \%$ kurang dari koefisien variansi Horwitznya, sehingga kedua jenis pelarut memiliki presisi yang baik. Hasil uji akurasi menunjukkan bahwa penentuan rhodamin B secara spektrofotometri UV-Vis dengan pelarut metanol dan etanol memiliki akurasi yang baik dengan rata-rata $82,68 \%$ dan $93,18 \%$. Kedua jenis pelarut memberikan persen recovery yang berada pada rentang $80-110 \%$. Penggunaan pelarut etanol memberikan akurasi yang lebih tinggi dibandingkan dengan pelarut metanol. Berdasarkan hasil uji statistika dengan selang kepercayaan 95\% diperoleh nilai $t_{\text {hitung }}=1,5123<t_{\text {tabel }}=2,5706$. Berdasarkan hasil uji statistik menunjukkan bahwa tidak ada perbedaan signifikan terhadap akurasi pengujian rhodamin B dengan pelarut metanol dan etanol. Kandungan rhodamin $\mathrm{B}$ dalam contoh saos yang dianalisis menggunakan pelarut metanol dan etanol adalah 2,4811 $\pm 0,3378 \mathrm{mg} / \mathrm{kg}$ dan $2,4217 \pm 0,4158 \mathrm{mg} / \mathrm{kg}$.

\section{Daftar Pustaka}

[1] W., Judarwanto, "Perilaku Makan Anak Sekolah," Persi, Jakart, 2009.

[2] H.S., Chen, "Identification of Rhodamine $6 \mathrm{~g}$ and Rhodamine B dyes present in ballpoint pen inks using high-performance liquid chromatography and UV-Vis spectrometry," Forensic Science Journal, vol 6, pp. 21-37, 2007.

[3] E., Kumalasari, "Identfikasi dan Penetapan Kadar Rhodamin B dalam Kerupuk Berwarna Merah yang Beredar di pasar Antasari Kota Banjarmasin," Jurnal Ilmiah Manuntung, vol 1, pp. 85-89, 2015.

[4] P. V. Y., Yamlean, "Identifikasi dan Penetapan Kadar Rhodamin B pada Jajanan Kue Berwarna Merah Muda yang Beredar di Kota Monado," Jurnal Ilmiah Sains, vol 11, pp. 289-295, 2011.

[5] R.A., Ali, O. M., Abdulmunem, and A. N., Abd, "Study the spectroscopic characteristics of Rhodamine B Dye in Ethanol and Methanol mixture and Calculation the Quantum Efficiency," Baghdad Science Journal, vol 9, pp. 252-358, 2012.

[6] N., Ozkantar, M., Soylak, M. T., Uzen, M.T., "Spectrophotometric detection of rhodamine B in tap water, lipstick, rouge, and nail polish samples after supramolecular solvent microextraction," Turkish Journal of Chemistry, vol 41, pp. 987-994, 2017. 